\title{
Family Business Experts: How to Survive the Holidays
}

\author{
Kimberly Eddleston (Northeastern University)
}

\author{
KEYWORDS: Family Business, Conflict, family \\ relationships.
}

While the holidays are supposed to bring magic and joy to people's lives, they are also an immense source of anxiety and stress. Family can be the root cause of this stress -- and families who run businesses together often have another layer of angst, especially when they take business difficulties home for the holidays.

Even for people who don't work together, family obligations, traditions, reunions and dinners are a reminder of how our family does not resemble the Norman Rockwell ideal. It can be worse for people who spend day after day working side by side. A brief, uncomfortable exchange of comments can pass and fade, or it can become something more loaded and deepen resentment. Family gatherings can conjure unhappy memories, remind family members of failures and shortcomings at home and at work, and force them to spend time with toxic relatives.

Family members often overstep boundaries by asking personal and uncomfortable questions (i.e. When are you getting married? What is the salary of your new job?), and broaching sensitive topics that are bound to end in a heated argument (i.e. politics, religion). Being around siblings also brings us back to the deep-rooted routines and bad habits of our childhood, where old wounds resurface and we are tempted to push one another's buttons. This family baggage often results in tension, resentment, and anger, and on the way home guilt.

Over the years, I have offered business-owning families much advice on dealing with family over the holidays. For example, taking inspiration from a Bob's Burgers episode ("Father of the Bob,"(https://bobsburgers.fandom.com/wiki/Father_of_the_Bob) Season 5, Episode 6), I have advised family members to limit their interaction with toxic relatives to under 15 minutes. Short encounters can help ensure that the conversation is pleasant and the relative does not have time to start an argument, give an insult, or ask an inappropriate question. Routinely staying in the kitchen to cook or do dishes is also a great way to limit one's interaction with difficult relatives. Television (i.e. football game, holiday special) is always a distraction from unpleasant interaction. A dog that needs a walk is another great escape. Alternatively, you can do what my close friend does - miss family gatherings by going on a vacation over the holidays.

In an effort to offer a diverse array of advice to families looking to successfully navigate the holidays, I asked some family business experts to share some of their favorite tips.

\section{Focus on the Positive}

"Don't expect your relatives will change, but focus on the qualities you like about them, rather than on the negative, and sweep away controversial discussion topics such as those about politics, sport and conjugality. Most importantly, don't drink too much as alcohol does not help to control your reactions and thoughts, and try to get engaged in group activities that require concentration such as playing bingo or cards as these help relieve stress and tensions. At some point, I typically pretend I have problems digesting all the food we have over the long Italian gathering, and go out for a long walk alone, which helps me to refresh my mind and improve my mood." -- Alfredo DeMassis,Ph.D., Free University of Bozen-Bolzano and Director of its Centre for Family Business Management

"This season, give the gift of generosity: shower your family members with gratitude, meet them with acceptance and patience, and don't forget that a little bit of humor goes a long way!" -- Claudia Astrachan Binz, Ph.D., Lucerne University of Applied Sciences and Arts

"Try to separate the personal from the professional and focus on the good aspects of the family only. -- Franz Kellermanns, Ph.D., UNC Charlotte, Director of its DBA program
Copyright ( 2021 The Authors. Entrepreneur \& Innovation Exchange is published at EIX.org. This is an open access article under the terms of the Creative Commons Attribution-NoDerivs License, which permits use and distribution in any medium, provided the original work is properly cited and no modifications or adaptations are made. View EIX.org Authorship Terms at https://eix.org/terms
FamilyBusiness 


\section{Bring on the Chocolate}

"Have a bowl of chocolate handy: It is known to produce endorphins; and the added benefit, it can quickly muzzle unwanted discussions." -- Torsten Pieper, Ph.D., UNC Charlotte and Editor of Journal of Family Business Strategy

\section{Be Your Best}

Taking inspiration from the famous quote, "Be the person your dog thinks you are!," I suggest handling family holiday challenges with: "Be the family leader the next generation thinks you are."-- Sherri Noxel, Ph.D., Director of the Austin Family Business Program at Oregon State University

\section{Avoid Minefields}

To keep the peace, my grandmother always reminds her children: "Do not start any difficult conversations with father at the Christmas table." -- Andrea Calabrò (https://nam05.safelinks.protection.outlook.com/?url=htt ps\%3A\%2F\%2Ffr.calameo.com\%2Fread\%2F0026756 09a0cad323c588\&data $=02 \% 7 C 01 \% 7 C k$.eddleston $\% 4$ Onortheastern.edu\%7C7071b3ba4d424d46e41008d77 e6da207\%7Ca8eec281aaa34daeac9b9a398b9215e7 $\% 7 C 0 \% 7 C 0 \% 7 C 637116881651462261 \&$ sdata=JtUd1 sljPovvl\%2B9biE4iXdIA12ljymvjTY1Rp0M6CwQ\%3D\& reserved=0) , Ph.D., IPAG Business School and Director of the STEP Project

"Plan the seating chart carefully (all family Fredos (https://familybusiness.org/content/the-fredo-factor-howdeadbeats-and-troublemakers) at the kids' table). If you can avoid it, don't talk about the family business it's safer perhaps to steer the conversation towards religion and politics."-- Roland Kidwell, Ph.D., Florida Atlantic University and Director of its Adams Center for Entrepreneurship

\section{Other Useful Tips}

In surviving Christmas, I try to live by some advice offered in an article in Der Spiegel on "How to survive amongst your loved ones":

Slow down a few days before Christmas. Go to the sauna on the $23^{\text {rd }}$, get a massage, go to the movies.

Differentiate between: What is important? What is not important? Simply because your mother in law notoriously cooks a seven course meal does not mean you have to do the same. Buy some cakes instead of cooking yourself. Develop your own rituals.
Reduce the number of gifts to a sensible level.

Coordinate with your partner: How do you want to celebrate?

And when nothing seems to help: Have a glass of sherry, and with an excuse step outside and take a deep breath. -- Thomas Zellweger, Ph.D., University of St. Gallen, and Director of the Swiss Research Institute of Small Business and Entrepreneurship (KMU-HSG) and the Global Center for Entrepreneurship and Innovation (GCEI-HSG).

We hope this advice leads to a happy holiday for you and your family!

\section{Learn More}

From Entitlement to Contribution (https://familybusiness.org/content/From-entitlement-tocontribution)

How to Bridge Generations in a Family Business (https://familybusiness.org/content/How-to-bridgegenerations-in-a-family-business)

Future Family Business Owners Can Learn to Manage Conflict(https://familybusiness.org/content/future-familybusiness-owners-can-learn-to-manag) 